
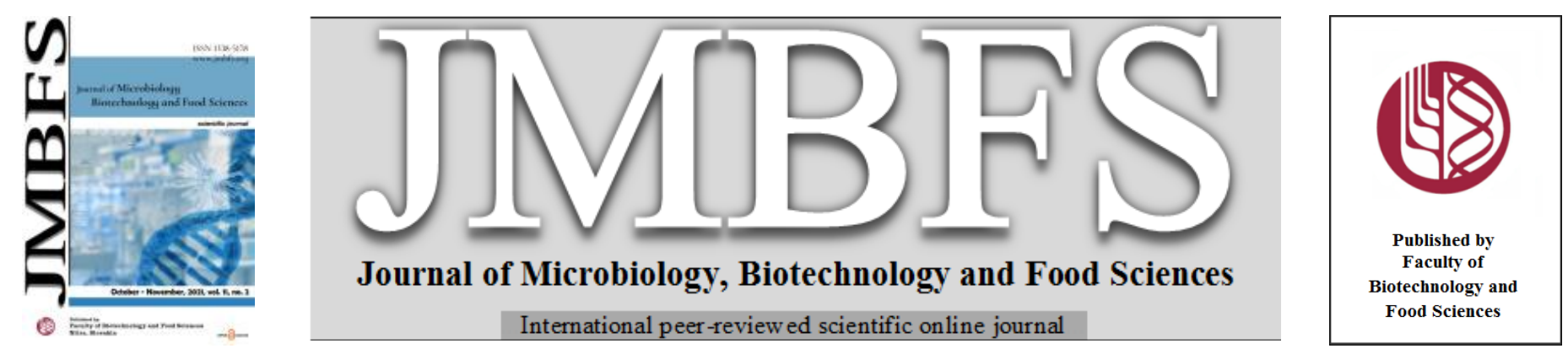

\title{
ARSENIC, CADMIUM AND MERCURY IN THE MACROLEPIOTA PROCERA (SCOP.) SINGER FRUITING BODIES
}

\author{
Ivona Jančo*l, Marek Šnirc ${ }^{1}$, Martin Hauptvogl ${ }^{2}$, Hana Franková ${ }^{1}$, Natália Čeryová ${ }^{1}$, Jana Štefániková ${ }^{3}$, Július Árvay $^{l}$
}

Address(es): Ing. Ivona Jančo

${ }^{1}$ Slovak University of Agriculture in Nitra, Faculty of Biotechnology and Food Sciences, Department of Chemistry, Tr. A. Hlinku 2, 94976 Nitra, Slovak Republic, phone number: +421 376414378.

${ }^{2}$ Slovak University of Agriculture in Nitra, Faculty of European Studies and Regional Development, Department of Environmental Management, Tr. A. Hlinku 2, 949 76 Nitra, Slovak Republic, phone number: +421 376415627.

${ }^{3}$ AgroBioTech Research Center, Tr. A. Hlinku 2, 94976 Nitra, Slovak Republic, phone number: +421 376414911.

*Corresponding author: xjanco@is.uniag.sk

https://doi.org/10.15414/jmbfs.4764

\section{ARTICLE INFO}

Received 7. 10. 2020

Revised 20. 4. 2021

Accepted 12. 5. 2021

Published 1. 10. 2021

Regular article oPEN $\partial_{\text {ACCESS }}$

\section{ABSTRACT}

In this study, the content of $\mathrm{As}, \mathrm{Cd}$ and $\mathrm{Hg}$ in fruiting bodies was determined. These three elements were determined in 94 Macrolepiota procera (Scop.) Singer samples (separately for caps and stems) and their corresponding soils/substrates collected from 8 different localities in Slovakia. Arsenic and cadmium were analyzed by Optical Emission Spectrometry with Inductively Coupled Plasma (OESICP), and mercury by Advanced Mercury Analyzer (AMA-254). In the soil/substrate As content varied from ND (not detected) to 11.9, $\mathrm{Cd}$ from 0.66 to 22.9 and $\mathrm{Hg}$ from 0.02 to $0.28 \mathrm{mg} \mathrm{kg}^{-1} \mathrm{DW}$ (dry weight), respectively. In fruiting body stems arsenic content varied from ND to 4.77, cadmium from ND to 5.96 and mercury from 0.03 to $2.83 \mathrm{mg} \mathrm{kg}^{-1} \mathrm{DW}$. In the caps, As content varied from ND to 13.0, Cd from ND to 19.8 and $\mathrm{Hg}$ from 0.04 to $4.00 \mathrm{mg} \mathrm{kg}^{-1} \mathrm{DW}$. After comparing obtained results with the EU limits, for As in mushrooms $6.6 \%$ (cap) of analyzed samples exceeded the limit value, while for $\mathrm{Cd}, 4.7 \%$ (cap), $2.0 \%$ (stem) of analyzed samples exceeded the limit value. Regarding the background values in the soils/substrates of selected elements in Slovakia only Cd exceeded the limits (though almost $82 \%$ of samples). Regarding $\mathrm{Hg}$ content, all analyzed samples (fruiting bodies and soils/substrates) did not exceed the limit value. The selected monitored localities in Slovakia have been contaminated with trace elements. Some of the analyzed mushroom samples exceeded EU limits, and as such, they can pose a risk to human health.

Keywords: Macrolepiota procera, Accumulation, Arsenic, Cadmium, Mercury

\section{INTRODUCTION}

Fungi are a very important part of ecosystems (Nnorom $\boldsymbol{e t}$ al., 2020). They are a highly biodiverse group of organisms and play various roles in nature, the economy, environmental and food science, health, and are involved in soil mineral weathering, organic substrate decomposition and elemental recycling. For centuries, edible mushrooms have been collected from forests, or later cultivated, and consumed due to their nutritional value and unique flavor (Rasalanavho et al., 2020; Olah et al., 2020). Edible mushrooms, due to their chemical composition, constitute a food of nutritional value. They have low-fat content and high contents of minerals, essential amino acids, vitamins and fiber. Mushrooms are important sources of polysaccharides with immunomodulation properties. Also, mushrooms contain several natural phytochemicals with a wide range of positive health effects and medicinal benefits (Reis et al., 2020). Macrolepiota procera (Scop.) Singer, an edible wild-growing mushroom belongs to Agaricaceae family and is a saprobe. This species is widely distributed in the northern areas of Asia and across Europe. Saprobic mushrooms usually live on dead vegetable matter in forests, and they are the only multi-celled organisms that can digest cellulose and lignin, the two major components of wood. According to that, mycorrhizal and saprobe mushrooms take part in a biogeochemical turnover of all mineral constituents in soil compartments or other substrates in which mycelium develops. It is known that M. procera is a good source of minerals, (especially $\mathrm{K}, \mathrm{Mg}$ and $\mathrm{Se}$ ), as well as carbohydrates, proteins, and dietary fibers. However, this species is also an accumulator of toxic elements such as $\mathrm{Cd}, \mathrm{Hg}$ and $\mathrm{Pb}$ (Đurđić et al., 2020).

Mining and other industrial activities contaminate the environment with toxic hazardous elements such as arsenic, cadmium, lead, copper and mercury. Compared to organic compounds, metals are not biodegradable and can bioaccumulate (causing them to enter the trophic chain) (Nnorom et al., 2020). Metal concentrations in mushrooms are considerably higher than those in crops, vegetables and fruits (Gebrelibanos et al., 2016). The accumulation of elements in mushrooms is affected by fungal (mushroom species, morphological part of the fruiting body, development stages, age of mycelium, and biochemical compositions) and environmental factors (e.g. presence of organic matter, $\mathrm{pH}$, metal concentrations in substrates) (Nnorom et al., 2020).

Since heavy metals could enter the food chain, for example, as a result of uptake by edible mushrooms, it is necessary to determine the levels of essential and nonessential metals and report possible contamination levels that could be the cause for health hazards (Gebrelibanos et al., 2016). Human exposure to toxic elements occurs through a variety of sources, which includes the consumption of contaminated foods and water as well as through the inhalation or dermal contact of air pollutants (Nnorom et al., 2020). Hazardous metals are toxic and their accumulation over time in human bodies could cause serious illnesses (Gebrelibanos et al., 2016). Cadmium (Cd) is a non-essential toxic heavy metal, an environmental toxicant, and toxic at a low concentration, and it has no known beneficial role in the human body (Kumar and Sharma, 2019). The intake of cadmium-contaminated food over years can result in the build-up of cadmium in different vital organs and tissues including the liver, kidneys, immune system, bone, and reproductive organs, but mostly in the kidney cortex, and if cumulative exposure is high enough, it may harm kidneys and bones and is a potent cause of cancer and cardiovascular diseases (Qasemi et al., 2019). Chronic As ingestion has been associated with varied clinical complications including skin lesions, diabetes mellitus, bronchitis, cardiovascular disease, peripheral neuropathy, adverse reproductive outcomes and hematological effects. Ingestion of high concentrations of As causes cancer of the skin, lung, urinary bladder, kidney and other malignancies (Sinha and Prasad, 2020). Mercury is highly toxic for living organisms and it has no role in biological functions (Shahid et al., 2020). Human exposure to $\mathrm{Hg}$ has been associated with numerous toxic effects on the immune, digestive and nervous systems, as well as on kidneys, lungs, eyes and skin. The WHO considers $\mathrm{Hg}$ as one of the top ten chemicals/substances of major public health concern (WHO, 2019). 
This study is part of a comprehensive survey to investigate arsenic, cadmium and mercury contents in macromycetes and their correspondent substrates to understand more the contamination by risk elements and the risk to local consumers in Slovakia. This review report $\mathrm{As}, \mathrm{Cd}$ and $\mathrm{Hg}$ concentrations in soil/substrate and $M$. procera from 8 different localities in Slovakia.

\section{MATERIAL AND METHODS}

\section{Study areas, sampling and samples preparation}

This study was carried out in Slovakia in 8 different localities (Figure 1). The basic characteristic of sampling areas is shown in Table 1 . The identification of the sampling areas was performed using GPS coordinates. In total, 94 samples of fresh fruiting bodies ( $M$. procera) directly after pickup, were cleaned up from any organic and inorganic debris with a ceramic knife and the bottom part of the stem was cut-off. Subsequently, they were divided into two parts - cap and stem and dried until DW at $40{ }^{\circ} \mathrm{C}$ in a laboratory heat-oven with forced air circulation (Memmert GmbH \& Co. KG, Schwabach, Germany) for 22 hours. Finally, they were pulverized in the rotary homogenizer (IKA-Werke $\mathrm{GmbH} \& \mathrm{Co} . \mathrm{KG}$, Staufen, Germany) and stored in polyethylene bags until further analysis. Soil/substrate samples were taken from the same location as mushrooms, from a depth of approximately $0.10 \mathrm{~m}$. The samples were dried for several weeks under laboratory conditions and then sieved through a pore size of $2 \mathrm{~mm}$ and stored in paper bags until analysis.

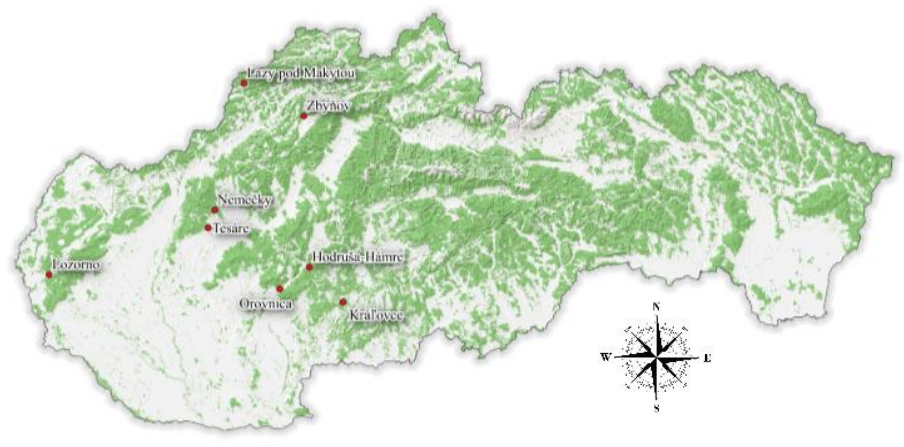

Figure 1 Map of sampling sites in Slovakia

\section{Samples analysis}

For this study, we decided to determine three elements: arsenic, cadmium and mercury. Total mercury concentration was determined by cold-vapor AAS analyzer AMA 254 (Advanced Mercury Analyzer, Altec, Czech Republic), separately in 94 samples of caps, stems and soils/substrates (282 samples in total). The mineralization was performed by using the pressure microwave digestion system (Ethos One, Milestone, Italy) in $5 \mathrm{~mL}$ of concentrated nitric acid $(69 \%$, trace purity) and $1 \mathrm{~mL}$ of hydrogen peroxide (30\%, trace purity) with the addition of $1 \mathrm{~mL}$ DI (deionized) water. The samples thus prepared were qualitatively and quantitatively analyzed by inductively coupled argon plasma emission spectrometry (ICP-OES) on an Agilent ICP-OES 720 (Agilent Technologies, USA). This method was used to determine arsenic and cadmium contents in samples.

Table 1 Sampling areas, number of samples and element contents in analyzed samples

\begin{tabular}{|c|c|c|c|c|c|c|c|c|c|c|}
\hline \multirow[t]{2}{*}{ Locality } & \multirow[t]{2}{*}{$\mathbf{n}$} & \multicolumn{3}{|c|}{$\begin{array}{c}\text { As }\left(\mathrm{mg} \mathrm{kg}^{-1} \mathrm{DW}\right) \\
\mathrm{AVG} \pm \mathrm{S} . \mathrm{D} . \\
\text { min-max }\end{array}$} & \multicolumn{3}{|c|}{$\begin{array}{c}\text { Cd }\left(\mathrm{mg} \mathrm{kg}^{-1} \mathrm{DW}\right) \\
\mathrm{AVG} \pm \mathrm{S} . \mathrm{D} . \\
\min -\max \end{array}$} & \multicolumn{3}{|c|}{$\begin{array}{c}\mathbf{H g}\left(\mathrm{mg} \mathrm{kg}^{-1} \mathrm{DW}\right) \\
\mathrm{AVG} \pm \mathrm{S} . \mathrm{D} . \\
\min -\max \end{array}$} \\
\hline & & Soil & Stem & Cap & Soil & Stem & Cap & Soil & Stem & Cap \\
\hline \multirow{2}{*}{$\begin{array}{l}\text { Hodruša- } \\
\text { Hámre }\end{array}$} & \multirow{2}{*}{16} & $4.04 \pm 3.40$ & $0.94 \pm 1.35$ & $2.71 \pm 2.72$ & $10.6 \pm 7.11$ & $0.53 \pm 0.91$ & $2.09 \pm 4.23$ & $0.07 \pm 0.03$ & $0.63 \pm 0.39$ & $1.06 \pm 0.68$ \\
\hline & & ND-11.8 & ND-4.77 & ND-9.41 & $3.08-22.9$ & ND-3.67 & $0.32-18.4$ & $0.03-0.14$ & 0.04-1.59 & $0.07-2.85$ \\
\hline \multirow{2}{*}{ Král'ovce } & \multirow{2}{*}{20} & $7.38 \pm 2.34$ & $1.21 \pm 0.81$ & $1.82 \pm 1.27$ & $5.84 \pm 1.19$ & $1.27 \pm 1.55$ & $2.41 \pm 3.47$ & $0.07 \pm 0.05$ & $0.73 \pm 0.23$ & $0.88 \pm 0.30$ \\
\hline & & $3.56-11.9$ & ND-2.70 & ND-4.82 & $3.35-8.25$ & $0.15-5.52$ & $0.23-13.1$ & $0.03-0.28$ & $0.44-1.59$ & $0.44-1.72$ \\
\hline \multirow{2}{*}{$\begin{array}{l}\text { Lazy pod } \\
\text { Makytou }\end{array}$} & \multirow{2}{*}{12} & $4.15 \pm 2.08$ & $0.39 \pm 0.52$ & $0.54 \pm 0.87$ & $5.21 \pm 1.25$ & $0.66 \pm 0.48$ & $1.36 \pm 1.11$ & $0.09 \pm 0.02$ & $1.46 \pm 0.64$ & $2.28 \pm 0.84$ \\
\hline & & $0.94-7.95$ & ND-1.37 & ND-2.82 & $3.19-7.39$ & $0.29-1.84$ & ND-3.87 & $0.06-0.13$ & $0.67-2.83$ & $1.22-4.00$ \\
\hline \multirow{2}{*}{ Lozorno } & \multirow{2}{*}{8} & $1.51 \pm 1.29$ & $0.35 \pm 0.61$ & $1.24 \pm 2.39$ & $1.12 \pm 0.63$ & $1.22 \pm 1.41$ & $4.94 \pm 6.30$ & $0.04 \pm 0.02$ & $1.19 \pm 0.69$ & $1.59 \pm 0.88$ \\
\hline & & ND-3.09 & ND-1.53 & ND-7.28 & $0.66-2.73$ & $0.21-3.67$ & $0.24-19.8$ & $0.02-0.07$ & $0.03-2.17$ & $0.04-2.86$ \\
\hline \multirow{2}{*}{ Nemečky } & \multirow{2}{*}{6} & $2.53 \pm 1.66$ & $0.50 \pm 1.12$ & $1.40 \pm 2.33$ & $3.24 \pm 0.33$ & $0.24 \pm 0.02$ & $0.41 \pm 0.27$ & $0.12 \pm 0.07$ & $0.73 \pm 0.16$ & $1.03 \pm 0.26$ \\
\hline & & $0.01-4.96$ & ND-3.00 & ND-6.54 & $2.85-3.89$ & $0.21-0.28$ & $0.03-0.80$ & $0.07-0.27$ & $0.58-1.04$ & $0.49-1.37$ \\
\hline \multirow{2}{*}{ Orovnica } & \multirow[b]{2}{*}{8} & $2.84 \pm 1.87$ & $0.68 \pm 1.16$ & $3.98 \pm 4.23$ & $3.74 \pm 0.26$ & $0.06 \pm 0.06$ & $0.69 \pm 0.17$ & $0.07 \pm 0.00$ & $0.79 \pm 0.22$ & $1.43 \pm 0.41$ \\
\hline & & ND-5.28 & ND-3.59 & ND-13.0 & $3.30-4.13$ & ND-0.16 & $0.39-0.95$ & $0.06-0.07$ & $0.51-1.15$ & $0.95-2.15$ \\
\hline \multirow{2}{*}{ Tesáre } & \multirow{2}{*}{15} & $3.19 \pm 1.84$ & $0.27 \pm 0.99$ & $1.79 \pm 1.45$ & $2.69 \pm 0.35$ & $0.94 \pm 4.41$ & $1.72 \pm 3.10$ & $0.08 \pm 0.02$ & $0.88 \pm 0.22$ & $1.21 \pm 0.28$ \\
\hline & & ND-6.12 & ND-3.98 & ND-4.98 & $2.14-3.30$ & $0.26-5.96$ & $0.30-13.1$ & $0.05-0.11$ & $0.61-1.35$ & $0.81-1.66$ \\
\hline \multirow{2}{*}{ Zbyňov } & \multirow{2}{*}{9} & $5.91 \pm 2.54$ & $0.35 \pm 0.54$ & $0.49 \pm 0.54$ & $6.00 \pm 1.42$ & $0.84 \pm 0.32$ & $1.60 \pm 0.57$ & $0.13 \pm 0.01$ & $1.06 \pm 0.46$ & $1.93 \pm 0.66$ \\
\hline & & $2.79-9.85$ & ND-1.41 & ND-1.48 & $3.50-9.02$ & $0.52-1.57$ & $1.03-2.82$ & $0.11-0.15$ & $0.07-1.76$ & $1.06-3.26$ \\
\hline
\end{tabular}

\section{Statistical analysis}

XLSTAT was used to calculate the average (AVG), standard deviation (S.D.), minimum and maximum values for each sample (Addinsoft, 2014). Two-way analysis of variance (ANOVA) was used to determine the differences between localities and after, the data were subjected to a t-test to compare each locality with the average value. Pearson's correlation coefficient was used to determine the statistical relationship between tested variables, soils/substrates and mushrooms, with a significant level $\mathrm{p}<0.05$. All statistical operations were performed using $\mathrm{R}$ studio version 1.2.5033 (RStudio Team, 2020).

\section{RESULTS AND DISCUSSION}

Arsenic, cadmium and mercury contents in analyzed samples (mushrooms and soil/substrate) are shown in Table 1.

\section{Arsenic (As)}

The arsenic concentration in the soil/substrate varied from ND to $11.9 \mathrm{mg} \mathrm{kg}^{-1} \mathrm{DW}$ The highest arsenic average concentration was measured at locality Královce (7.38 $\left.\pm 2.34 \mathrm{mg} \mathrm{kg}^{-1} \mathrm{DW}\right)$ and the lowest in Nemečky $\left(2.53 \pm 1.66 \mathrm{mg} \mathrm{kg}^{-1} \mathrm{DW}\right)$. In mushroom stems, the highest average arsenic concentration was detected just like in the soil/substrate (Král'ovce) and it was $1.21 \pm 0.81 \mathrm{mg} \mathrm{kg}^{-1} \mathrm{DW}$ but the lowes $\left(0.27 \pm 0.99 \mathrm{mg} \mathrm{kg}{ }^{-1} \mathrm{DW}\right)$ was detected at locality Tesáre. Arsenic content in mushroom caps varied from ND to $13.0 \mathrm{mg} \mathrm{kg}^{-1} \mathrm{DW}$. The highest average concentration was $3.98 \pm 4.23 \mathrm{mg} \mathrm{kg}^{-1} \mathrm{DW}$ (Orovnica) and the lowest $0.49 \pm 0.54 \mathrm{mg}$ $\mathrm{kg}^{-1} \mathrm{DW}$ (Zbyňov)

The highest arsenic concentrations (for soil and cap) were measured at locality Královce, which is following the fact that this locality is classified to the $2^{\text {nd }}$ environmental region quality (regions with moderately disturbed environment) (Environmental regionalization of the Slovak Republik, 2016).

According to the EU limit value, the limit in edible mushroom (both, cap and stem) for As is $0.50 \mathrm{mg} \mathrm{kg}^{-1}$. Compared with this, $6.6 \%$ of mushroom caps exceeded the limit, while all of the mushroom stems were below the limit value. For soil/substrate, the background value for As in Slovakia is $6.80 \mathrm{mg} \mathrm{kg}^{-1}$ (Šefčík $\boldsymbol{e}$ al., 2008) and compared with this, all measured soil/substrate samples did not exceed the background value.

Stefanović et al. (2016) studied Ag, Se and As concentration in M. procera $(\mathrm{n}=41)$ and its soil/substrate $(n=30)$ from Serbia. The content of total arsenic in caps of investigated $M$. procera ranged from below the detection limit $\left(0.01 \mathrm{mg} \mathrm{kg}^{-1} \mathrm{DW}\right)$ to $3.40 \mathrm{mg} \mathrm{kg}^{-1} \mathrm{DW}$. Average concentrations were ranging from $0.50 \pm 0.10$ to $1.80 \pm 1.30 \mathrm{mg} \mathrm{kg}^{-1} \mathrm{DW}$ for caps and from $0.50 \pm 0.40$ to $1.30 \pm 0.80 \mathrm{mg} \mathrm{kg}^{-1} \mathrm{DW}$ for stems. Vetter (2004) analyzed arsenic contents of 162 fruit body samples of 37 common edible mushrooms (Hungary). Notable arsenic contents were measured in different Agaricus, Lepista and Macrolepiota species. In Macrolepiota procera the average arsenic concentration was $4.84 \pm 5.67 \mathrm{mg} \mathrm{kg}^{-1} \mathrm{DW}$. The highest arsenic levels were found in fruit bodies of Laccaria amethysthea (147 mg kg-1 DW), and Macrolepiota rhacodes $\left(42.6 \mathrm{mg} \mathrm{kg}^{-1} \mathrm{DW}\right)$, respectively. Their measured data demonstrated the role of the taxonomic position of the mushroom in arsenic uptake and content. The arsenic-accumulating capacity (ability) of macroscopic edible mushrooms were found in two orders of the class Basidiomycetes (Agaricales and Gasteromycetales). Some taxa of these orders can accumulate high amounts of arsenic and this phenomenon seems to be independent of their habitats. 
As part of the statistical analysis, we used a boxplot for graphically depicting groups of numerical data through their quartiles. Figure 2 shows the relationship between locality and the analyzed sample. There is a strongly significant difference between locality and soil/substrate $\left(\mathrm{p}=2.2 \mathrm{e}^{-07}\right)$. A strong difference is between two localities and soil: soil/Král'ovce and soil/Lozorno, while even though between soil/Tesáre there is a significant difference, it is very low. Lozorno is significantly lower, and Královce is
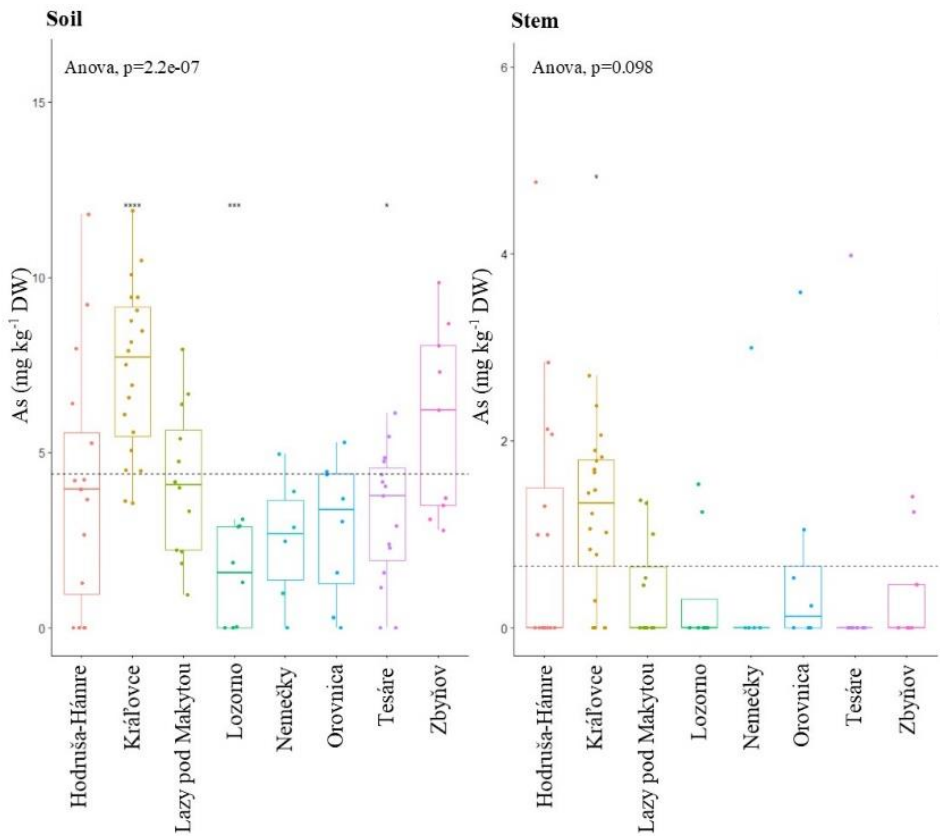

significantly higher in the proliferation group (Figure 2). Considering mushroom stems, we can say that there are no significant differences between locality/stem, since $\mathrm{p}=0.098$. The only difference is between stem/Královce and it is very low. Nemečky and Tesáre are significantly lower and Královce is significantly higher in the proliferation group. The relationship between locality and cap showed that there is a low significant difference, $\mathrm{p}=0.016$, but a strong significant difference was found in cap/Lazy pod Makytou and a very strong significant difference in cap/Zbyňov. From Figure 2 we can conclude that results from Orovnica are significantly higher and Lazy pod Makytou is significantly lower in the proliferation group. These boxplots statistically confirmed measured data.

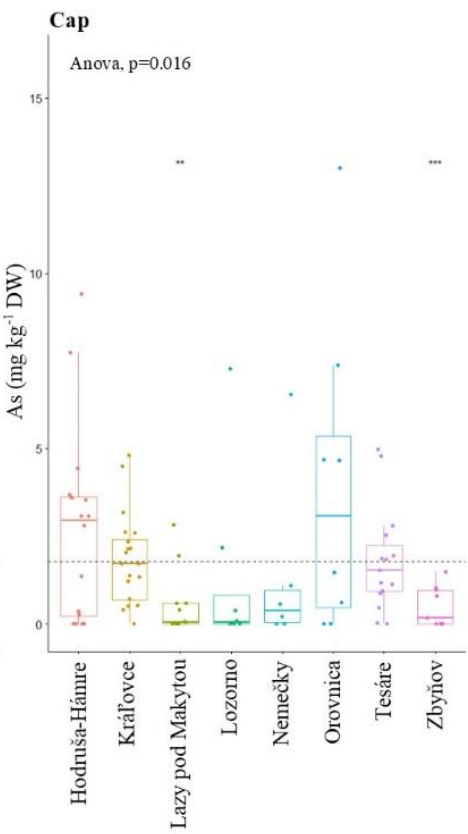

Figure 2 Arsenic concentrations in mushrooms and soils/substrates, concerning localities. The dashed line presents the average concentration for soil, stem and cap samples, separately. Note: The lowest data point presents minimum data value; the highest data point presents maximum data value; the middle value of the dataset presents median, and dots out of the box are outliers.

\section{Cadmium (Cd)}

The Cd concentration in the soil/substrate varied from 0.66 to $22.9 \mathrm{mg} \mathrm{kg}^{-1} \mathrm{DW}$ (Table 1). The highest cadmium average concentration was measured in HodrušaHámre $\left(10.6 \pm 7.11 \mathrm{mg} \mathrm{kg}^{-1} \mathrm{DW}\right)$ and the lowest in Lozorno $\left(1.12 \pm 0.33 \mathrm{mg} \mathrm{kg}^{-1}\right.$ DW). In mushroom stems, the highest average cadmium concentration was detected in Král'ovce $\left(1.27 \pm 1.55 \mathrm{mg} \mathrm{kg}^{-1} \mathrm{DW}\right)$ and the lowest $\left(0.06 \pm 0.48 \mathrm{mg} \mathrm{kg}^{-1}\right.$ DW) was detected in Orovnica. Cd content in mushroom caps varied from ND to $19.8 \mathrm{mg} \mathrm{kg}^{-1} \mathrm{DW}$. The highest average concentration was $4.94 \pm 6.30 \mathrm{mg} \mathrm{kg}^{-1} \mathrm{DW}$ (Lozorno) and the lowest $0.41 \pm 0.27 \mathrm{mg} \mathrm{kg}^{-1} \mathrm{DW}$ (Nemečky).
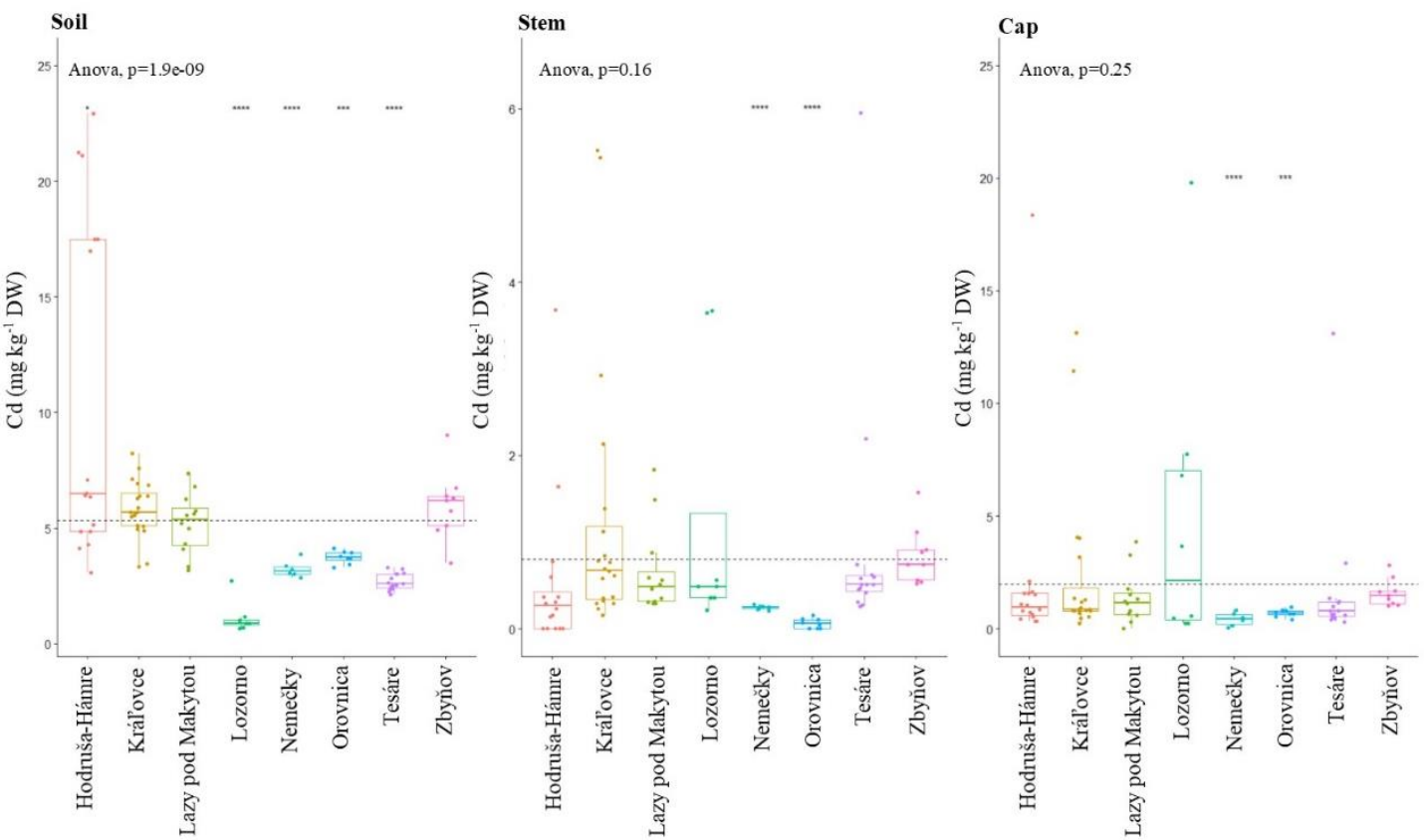

The highest cadmium concentration (in soil/substrate) was measured in HodrušaHámre and this is because the samples were collected from the mining area, but the highest cadmium concentration in caps was detected in Král'ovce, that is following the fact that this locality (Královce) belongs to the $2^{\text {nd }}$ environmental region quality (regions with moderately disturbed environment). 
Figure 3 Cadmium concentrations in mushrooms and soils/substrates, concerning localities. The dashed line presents the average concentration for soil, stem and cap samples, separately. Note: The lowest data point presents minimum data value; the largest data point presents maximum data value; the middle value of the dataset presents median, and dots out of the box are outliers. According to the EU limit value, the limit in edible mushrooms (both, cap and stem) for $\mathrm{Cd}$ is $0.50 \mathrm{mg} \mathrm{kg}^{-1}$. In concordance with this, almost $2.0 \%$ of mushroom stems and $4.7 \%$ of mushroom caps exceeded the limit. For soil/substrate, the background $\mathrm{Cd}$ value in Slovakia is $0.20 \mathrm{mg} \mathrm{kg}^{-1}$ (Šefč́́k et al., 2008) and compared with this, almost $82 \%$ of samples exceeded the background value. Árvay et al. (2014) analyzed 92 samples (12 species) of wild edible mushrooms in the Slovak Paradise National Park, that borders with a region of historical mining and processing of polymetallic ore, and they find out that the cadmium content in caps of analyzed mushroom exceeded statutory limits in $96 \%$ of the samples. Jančo et al. (2019) examined selected risk elements $(\mathrm{Cd}, \mathrm{Pb}$ and $\mathrm{Hg})$ contamination in 50 samples of $M$. procera. The cadmium content in mushroom caps varied from ND to $19.8 \mathrm{mg} \mathrm{kg}^{-1} \mathrm{DW}$ and the highest average concentration was in Lozorno (4.94 $\left.\mathrm{mg} \mathrm{kg}^{-1} \mathrm{DW}\right)$ and the lowest in Nemečky $\left(0.41 \mathrm{mg} \mathrm{kg}^{-1} \mathrm{DW}\right)$ Considering the admissible limit for $\mathrm{Cd}$ in edible mushrooms, $76 \%$ of samples exceeded the limit. The $\mathrm{Cd}$ content in stems varied from 0.21 to $3.67 \mathrm{mg} \mathrm{kg}^{-1} \mathrm{DW}$ When considering the EU limit, $54 \%$ of mushroom stem samples were above the limit.

Figure 3 shows the relationship between locality and the analyzed sample. There is a strongly significant difference between locality and soil/substrate $\left(\mathrm{p}=1.9 \mathrm{e}^{-09}\right)$ A strong difference is between four localities and soil: soil/Orovnica, soil/Lozorno, soil/Nemečky and soil/Tesáre, while between soil/Hodruša-Hámre there is a low significant difference. Figure 3 shows that Lozorno is significantly lower, and Hodruša-Hámre is significantly higher in the proliferation group. Considering mushroom stems, we can say that there are no significant differences between locality/stem, since $\mathrm{p}=0.16$, but there is a very strong difference between stem/Orovnica and stem/Nemečky. Orovnica is significantly lower and Lozorno is significantly higher in the proliferation group. The relationship between locality and cap showed that there is no significant difference, $p=0.25$, but a very strong significant difference was found in cap/Nemečky and cap/Orovnica. From Figure 3 , we can conclude that Lozorno is significantly higher and Nemečky is significantly lower in the proliferation group.

\section{Mercury (Hg)}

The mercury content in the soil/substrate varied from 0.02 to $0.28 \mathrm{mg} \mathrm{kg}^{-1} \mathrm{DW}$ (Table 1). The highest $\mathrm{Hg}$ average soil concentration was measured at locality Zbyňov $\left(0.13 \pm 0.01 \mathrm{mg} \mathrm{kg}^{-1} \mathrm{DW}\right)$ and the lowest one in Lozorno $(0.04 \pm 0.02 \mathrm{mg} \mathrm{kg}$ $\left.{ }^{1} \mathrm{DW}\right)$. In mushroom stems, the highest average mercury concentration was detected at locality Lazy pod Makytou and it was $1.46 \pm 0.64 \mathrm{mg} \mathrm{kg}^{-1} \mathrm{DW}$ and the lowest detected $\mathrm{Hg}$ concentration was $0.63 \pm 0.39 \mathrm{mg} \mathrm{kg}^{-1} \mathrm{DW}$ (Hodruša-Hámre). $\mathrm{Hg}$ content in mushroom caps varied from 0.04 to $4.00 \mathrm{mg} \mathrm{kg}^{-1} \mathrm{DW}$. The highes average concentration was $2.28 \pm 0.57 \mathrm{mg} \mathrm{kg}^{-1} \mathrm{DW}$ (Lazy pod Makytou) and the lowest $0.88 \pm 0.30 \mathrm{mg} \mathrm{kg}^{-1} \mathrm{DW}$ (Král'ovce).

The highest mercury concentrations were measured at localities Zbyňov and Lazy pod Makytou, even though these localities belong to the $1^{\text {st }}$ environmental region quality (regions with the undisturbed environment). This fact can be explained by the high ability of $M$. procera to accumulate mercury, even those concentrations which are considered to be negligible.
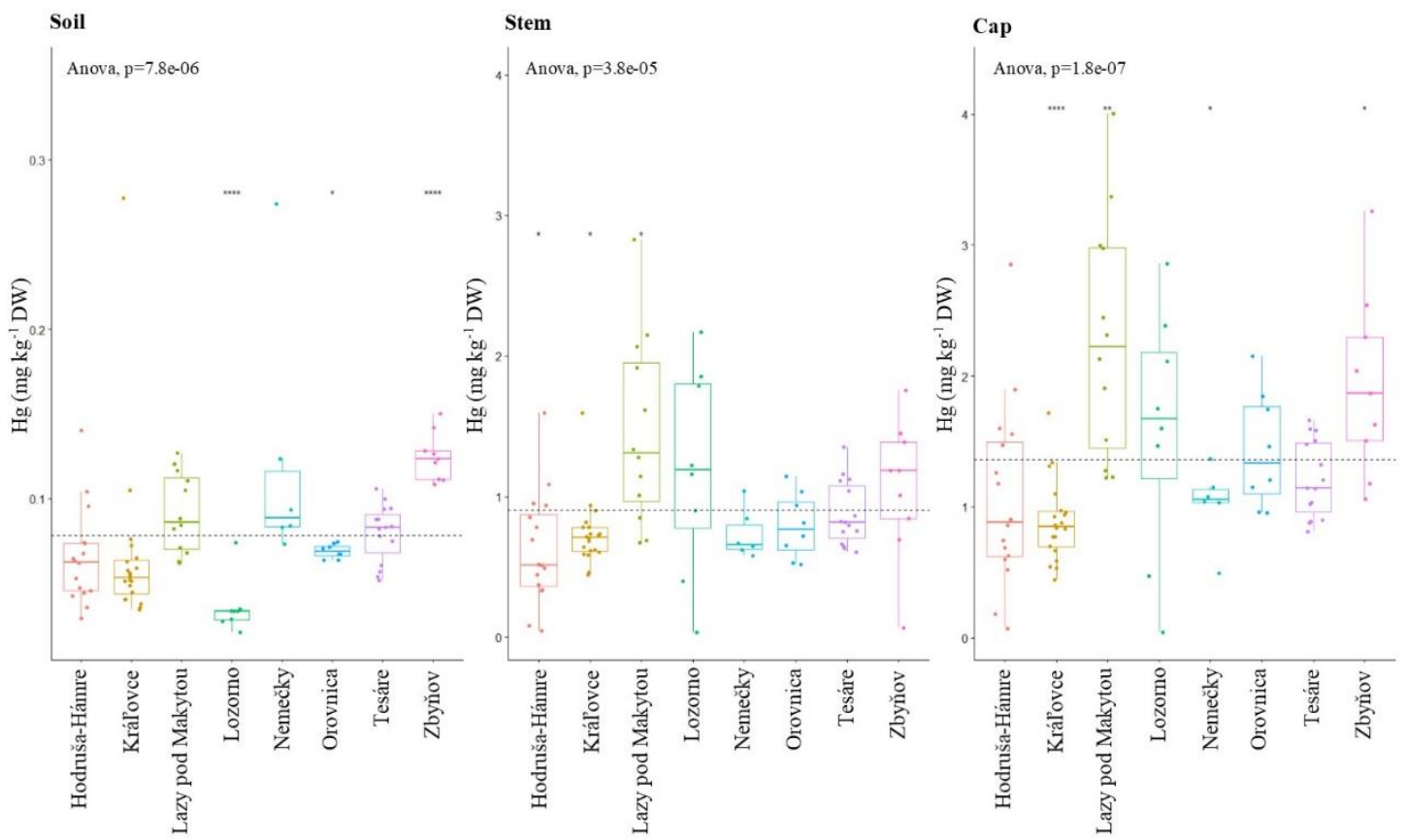
Figure 4 Mercury concentrations in mushrooms and soils/substrates, concerning localities. The dashed line presents the average concentration for soil, stem and cap samples, separately. Note: The lowest data point presents minimum data value; the largest data point presents maximum data value; the middle value of the dataset presents median, and dots out of the box are outliers.

Depending on the fruiting body collection site, there can be a higher, lower, or significantly differentiated ability of mushrooms to accumulate individual elements/metals. However, the efficiency of element accumulation depends not only on their concentration in a substrate, but also on mushroom species, genus, or the families to which they belong (Mleczek et al., 2020b). The hypothesis that the increasing age of mycelium and a protracted interval between fructifications significantly elevate the contents of many elements in fruiting bodies and usually higher levels occur in caps than in stems (Kalač, 2019). This is also in accordance with our measured data; the higher levels were detected in caps than in stems.

\section{Pearson's correlation test}

Pearson's correlation test (significant level $\mathrm{p}<0.05$ ) was used to determine the relationship between the variables, in our case: analyzed samples (mushrooms and soils/substrates) and selected risk elements (As, $\mathrm{Cd}$ and $\mathrm{Hg}$ ) (Figure 5).

Regarding arsenic content, between stem/cap was found a positive weak correlation. Between soil/stem there was no correlation found and in soil/cap there was found a weak negative correlation. This shows that the detected As content in the fruiting bodies is not from the soil/substrate, but yet arsenic was passed from cap to stem, so we can say that the detected arsenic content was from the atmospheric origin. A very strong positive relationship between stem/cap was detected (for $\mathrm{Cd}$ ) and this fact confirmed the element translocation between stem and cap. In the case of the relationship between soil/stem, there was no relationship found, but in soil/cap there was found a very weak positive relationship, that can be considered as negligible. From these findings, we can conclude that the majority part of the detected $\mathrm{Cd}$ in mushroom fruiting bodies is of atmospheric origin. It was detected a very strong positive relationship between stem/cap and a strong positive relationship between soil/stem and soil/cap, according to $\mathrm{Hg}$ content From this, we can claim that the mercury from soil/substrate passes into the stem and is translocated to the cap, where it concentrates, which shows that the detected mercury in mushroom samples was mainly from the soil/substrate as part of the nutrition uptake.

However, there was found a relatively strong positive correlation between $\mathrm{Cd}$ and As contents in soil/substrate. It is because the analyzed samples were taken from the same localities and according to this, we can say that the soils/substrates contain As and Cd, even though in small quantities. But it also confirms that the detected concentrations of $\mathrm{Cd}$ and $\mathrm{As}$ in fruiting bodies were taken from the atmosphere since there was detected a positive correlation between $\mathrm{Cd}$ cap and As cap.

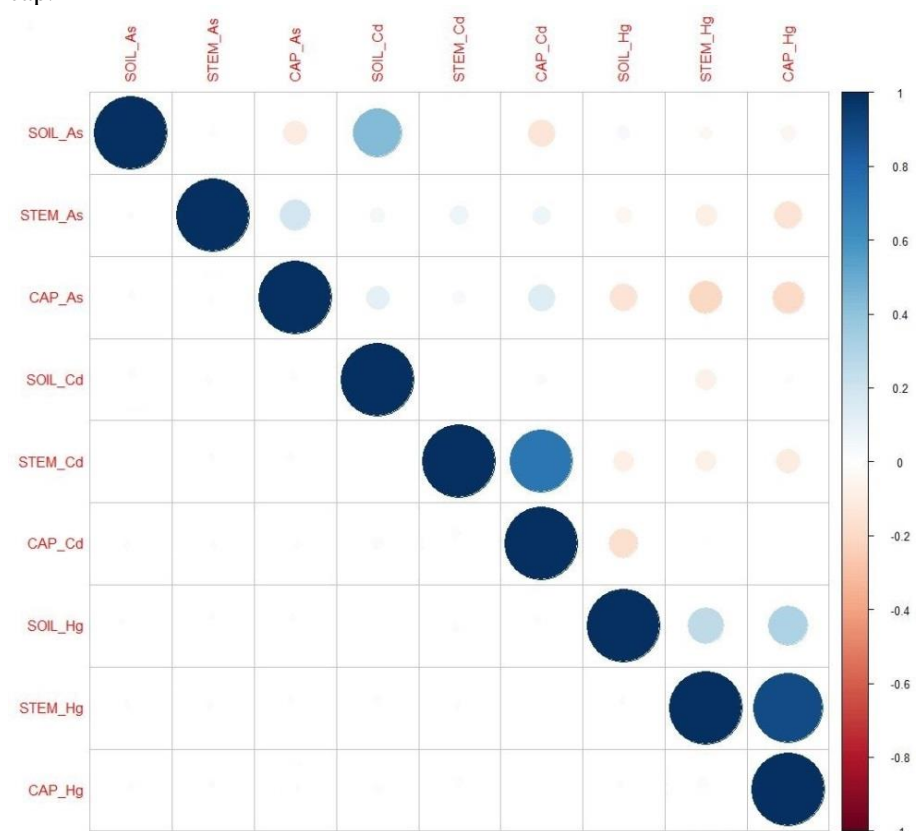

Figure 5 Relationship between $\mathrm{As}, \mathrm{Cd}$ and $\mathrm{Hg}$ contents in mushrooms (caps/stems) and soils/substrates

\section{Health risk assessment}

Based on the total mercury content determined in the studied biological samples and their average weekly consumption, Provisional Tolerable Weekly Intake PTWI (\%) was estimated. The percentage of PTWI assesses the health risk from exposure to the toxic element. To determine the percentage of PTWI for $\mathrm{Hg}$ derived from the consumption of the studied mushroom species, concentration levels and consumption levels were combined. The \%PTWI was calculated for the whole fruiting body using concentration data obtained for each anatomic part. The percentage excess of tolerable weekly intakes per person weighing $70 \mathrm{~kg}$ for $\mathrm{Hg}$ is $0.28 \mathrm{mg}$ person per week and for $\mathrm{Cd}$ is $0.44 \mathrm{mg}$ person per week (JECFA, 2011) and the average consumption of "Other vegetables and mushrooms" in Slovakia was $0.23 \mathrm{~kg}$ person per week in 2018 (Statistical Organization of Slovak Republic, 2019). It was calculated as follows:

$$
\text { PTWI (\%) }=\frac{\text { element content in BS x } 0.23}{\text { element PTWI }} \times 100
$$

where: $\boldsymbol{B S}$ is the measured concentration of a selected element $(\mathrm{Hg})$ in the biological sample ( $\mathrm{mg} \mathrm{kg}^{-1}$ of fresh weight) in mushrooms). If the detected value was greater than $100 \%$, the consumption of mushroom samples from the area is potentially hazardous.

The PTWI for $\mathrm{Hg}$ is $300 \mu \mathrm{g}$ (equivalent to 5 or $0.7 \mu \mathrm{g} \mathrm{kg}^{-1}$ body weight (BW) per day), and a reference dose is $0.3 \mu \mathrm{g} \mathrm{kg}^{-1} \mathrm{BW}$ per day (JECFA 1978; US EPA 2005). PTWI for cadmium is $7 \mu \mathrm{g} \mathrm{kg}^{-1} \mathrm{BW}$ (equivalent to $1 \mu \mathrm{g} \mathrm{kg}^{-1} \mathrm{BW}$ per day) (European Food Safety Authority EFSA 2009). Results indicated that \%PTWI using mean $\mathrm{Hg}$ concentration values ranged between 7.30 and $18.7 \%$ PTWI for mushroom caps and in the range 5.10-12.0\%PTWI for mushroom stems. For Cd, PTWI ranged between 2.20 and $26.0 \%$ for mushroom caps, and in the range of 0.30 and $6.60 \%$ for mushroom stems. None of the analyzed samples did exceed the recommended daily intake.

Caps of $M$. procera can be large and are highly valued by the mushroom pickers, and all specimens found are collected. No doubt, some individuals from the local countryside populations and the cottage house owners or the camp tourists, temporarily, eat them even several times a week during the harvesting season. Hence, in a good "mushroom" year an abundance of this species will lead to a short time exposure of fanciers to elevated toxic elements (e.g. $\mathrm{Cd}$ and $\mathrm{Hg}$ ) doses that exceed the PTWI (Gucia et al., 2012).

\section{CONCLUSION}

Wild-growing mushrooms are consumed as a delicacy in many countries Extensive research has been carried out to investigate the accumulation of three selected toxic elements ( $\mathrm{As}, \mathrm{Cd}$ and $\mathrm{Hg}$ ) in edible wild-growing Macrolepiota procera and its corresponding soil/substrate. This research was carried out in 8 different localities in Slovakia. This study showed that the analyzed fruiting bodies and soil/substrate samples were contaminated with all of the selected elements and as such, they can pose a threat to human health. Statistical analysis confirmed the transport of trace elements (especially $\mathrm{Hg}$ ) from the soil to the mushroom (stem/cap).

Funding: This work was supported by the project VEGA No. 1/0591/18.

Acknowledgment: We would like to thank Romana Šmondrková, Viera Šišková, Martin Vídenský and Jozef Pavlík who have willingly helped us with the sampling.

\section{REFERENCES}

ADDINSOFT (2014) XLSTAT, Analyse de données et statistique avec MS Excel. Addinsoft, New York.

ÁRVAY, J., TOMÁS̆, J., HAUPTVOGL, M., KOPERNICKÁ, M., KOVÁČIK, A., BAJČAN, D., \& MASSÁNYI, P. (2014). Contamination of wild-grown edible mushrooms by heavy metals in a former mercury-mining area. Journal of Environmental Science and Health, Part B, 49(11), 815-827. https://doi.org/10.1080/03601234.2014.938550

ĐURĐIĆ, S., STANKOVIĆ, V., RAŽIĆ, S., \& MUTIĆ, J. (2020). Lead isotope ratios as tool for elucidation of chemical environment in a system of Macrolepiota procera (Scop.) Singer-soil. Environmental Science and Pollution Research, 1-12. https://doi.org/10.1007/s11356-020-07947-6

Environmental regionalization of the Slovak Republik (2016) https://www.minzp.sk/files/environmentalna-regionalizacia-sr.pdf

European Food Safety Authority (EFSA) (2009) Cadmium in food. EFSA J 980:1139.

http://wwwefsaeuropaeu/cs/BlobServer/Scientific_Opinion/contam_op_ej980_ca dmium_en_rev1pdf?ssbinary=true/. Cited 12 Dec 2009

FALANDYSZ, J., SAPKOTA, A., DRYŻAŁOWSKA, A., MĘDYK, M., \& FENG, X. (2017). Analysis of some metallic elements and metalloids composition and relationships in parasol mushroom Macrolepiota procera. Environmental Science and Pollution Research, 24(18), 15528-15537. https://doi.org/10.1007/s11356-017-9136-9

GEBRELIBANOS, M., MEGERSA, N. \& TADDESSE, A.M. (2016). Levels of essential and non-essential metals in edible mushrooms cultivated in Haramaya, Ethiopia. Food Contamination 3, 2. https://doi.org/10.1186/s40550-016-0025-7 
GUCIA, M., JARZYŃSKA, G., RAFAŁ, E., ROSZAK, M., KOJTA, A. K., OSIEJ, I., \& FALANDYSZ, J. (2012). Multivariate analysis of mineral constituents of edible Parasol Mushroom (Macrolepiota procera) and soils beneath fruiting bodies collected from Northern Poland. Environmental Science and Pollution Research, 19(2), 416-431. https://doi.org/10.1007/s11356-011-0574-5 JANČO, I., TREBICHALSKÝ P., BYSTRICKÁ J., TIRDIL'OVÁ, I \& ŠTEFÁNIKOVÁ J. (2019). Determination of cadmium, lead and mercury content in Macrolepiota procera in selected areas of Slovakia. International Multidisciplinary Scientific GeoConference: SGEM, 19(3.2), 681-688 https://doi.org/10.5593/sgem2019/3.2

JECFA (1978) Evaluation of certain food additives and contaminants Twentysecond report of the Joint FAO/WHO Expert Committee on Food Additives WHO Technical Report Series 631

JECFA, 2012. Safety Evaluation of Certain Food Additives, Prepared by the Seventy Fourth Meeting of the Joint FAO/WHO Expert. Committee on Food Additives (JECFA), Geneva

KALAČ, P. (2019) Mineral composition and radioactivity of edible mushrooms. Academic Press / Elsevier, ISBN 978-0-12-817565-1.

KUMAR, S., \& SHARMA, A. (2019). Cadmium toxicity: effects on human reproduction and fertility. Reviews on environmental health, 34(4), 327-338. https://doi.org/10.1515/reveh-2019-0016

MLECZEK, M., BUDKA, A., KALAČ, P., SIWULSKI, M., \& NIEDZIELSKI, P. (2020b). Family and species as determinants modulating mineral composition of selected wild-growing mushroom species. Environmental Science and Pollution Research, 1-16. https://doi.org/10.1007/s11356-020-10508-6

MLECZEK, M., SIWULSKI, M., BUDKA, A., MLECZEK, P., BUDZYŃSKA, S., SZOSTEK, M. \& GOLIŃSKI, P. (2020a). Toxicological risks and nutritional value of wild edible mushroom species-a half-century monitoring study. Chemosphere, 128095. https://doi.org/10.1016/j.chemosphere.2020.128095

NNOROM, I. C., EZE, S. O., \& UKAOGO, P. O. (2020). Mineral contents of three wild-grown edible mushrooms collected from forests of south eastern Nigeria: An evaluation of bioaccumulation potentials and dietary intake risks. Scientific African, 8, e00163. https://doi.org/10.1016/j.sciaf.2019.e00163

OLAH, B., KUNCA, V., \& GALLAY, I. (2020). Assessing the Potential of Forest Stands for Ectomycorrhizal Mushrooms as A Subsistence Ecosystem Service for Socially Disadvantaged People: A Case Study from Central Slovakia. Forests, 11(3), 282. https://doi.org/10.3390/f11030282

QASEMI, M., SHAMS, M., SAJJADI, S. A., FARHANG, M., ERFANPOOR, S., YOUSEFI, M. \& AFSHARNIA, M. (2019). Cadmium in groundwater consumed in the rural areas of Gonabad and Bajestan, Iran: occurrence and health risk assessment. Biological trace element research, 192(2), 106-115. https://doi.org/10.1007/s12011-019-1660-7

RASALANAVHO, M., MOODLEY, R., \& JONNALAGADDA, S. B. (2020), Elemental bioaccumulation and nutritional value of five species of wild growing mushrooms from South Africa. Food Chemistry, 126596. https://doi.org/10.1016/j.foodchem.2020.126596

REIS, G. C., CUSTÓDIO, F. B., BOTELHO, B. G., GUIDI, L. R., \& GLORIA, M. B. A. (2020). Investigation of biologically active amines in some selected edible mushrooms. Journal of Food Composition and Analysis, 86, 103375. https://doi.org/10.1016/j.jfca.2019.103375

RStudio Team (2020). RStudio: Integrated Development for R. RStudio, PBC, Boston, MA URL http://www.rstudio.com/.

ŠEFČÍK, P., PRAMUKA, S., \& GLUCH, A. (2008). Assessment of soil contamination in Slovakia according index of geoaccumulation. Agriculture (Slovak Republic). Agriculture 54 pp 119-130

SHAHID, M., KHALID, S., BIBI, I., BUNDSCHUH, J., NIAZI, N. K., \& DUMAT, C. (2020). A critical review of mercury speciation, bioavailability, toxicity and detoxification in soil-plant environment: Ecotoxicology and health risk assessment. Science of The Total Environment, 711, 134749. https://doi.org/10.1016/j.scitotenv.2019.134749

SINHA, D., \& PRASAD, P. (2020). Health effects inflicted by chronic low-level arsenic contamination in groundwater: A global public health challenge. Journal of Applied Toxicology, 40(1), 87-131. https://doi.org/10.1002/jat.3823

Statistical Organization of Slovak Republic, 2019. Food Consumption in the Slovak Republic 2018. (Available at: www.statistics.sk)

STEFANOVIĆ, V., TRIFKOVIĆ, J., DJURDJIĆ, S., VUKOJEVIĆ, V., TEŠIĆ, Ž., \& MUTIĆ, J. (2016). Study of silver, selenium and arsenic concentration in wild edible mushroom Macrolepiota procera, health benefit and risk. Environmental Science and Pollution Research, 23(21), 22084-22098. https://doi.org/10.1007/s11356-016-7450-2

US EPA (2005) Toxicological review of zinc and compounds. In support of summary information on the integrated risk information system. US Environmental Protection Agency, Washington DC

VETTER, J. (2004). Arsenic content of some edible mushroom species. European Food Research and Technology, 219(1), 71-74. https://doi.org/10.1007/s00217004-0905-6

WHO. 2019. Mercury and health. World Health Organization. Accessed on September 16, 2019: https://www.who.int/news-room/fact-sheets/detail/mercuryand-health. 